\title{
Synthesis, Spectral Characterization, Electron Microscopic Study and Influence on the Thermal Stability of Phosphorus-containing Dendrimer with a 4,4'-Sulphonyldiphenol at the Core
}

\author{
Echchukattula Dadapeer, Syed Rasheed, and Chamarthi Naga Raju*
}

\author{
Department of Chemistry, Sri Venkateswara University, Tirupat-517 502, India. *E-mail: rajuchamarthi10@gmail.com \\ Received September 21, 2010, Accepted November 30, 2010
}

\begin{abstract}
The divergent synthesis of novel phosphorus-containing dendrimer with 4,4'-sulphonyldiphenol at the core has been accomplished involving simple condensation reactions using $\mathrm{P}(\mathrm{O}) \mathrm{Cl}_{3}, \mathrm{P}(\mathrm{S}) \mathrm{Cl}_{3}, 3$-amino-phenol, 3-hydroxy-benzaldehyde, and 2-butyn 1, 4-diol. The final compound was a Schiff's base macromolecule possessing 4 imine bonds, 8 acetylenic bonds and $8 \mathrm{OH}$ groups at the periphery. The structures of intermediate compounds were confirmed by IR, NMR $\left({ }^{1} \mathrm{H}\right.$, ${ }^{13} \mathrm{C}$ and $\left.{ }^{31} \mathrm{P}\right)$, LC-Mass and $\mathrm{C}, \mathrm{H}, \mathrm{N}$ analysis. The structure of the final dendrimer $(\mathbf{5})$ was confirmed by IR, NMR $\left({ }^{1} \mathrm{H},{ }^{13} \mathrm{C}\right.$ and ${ }^{31} \mathrm{P}$ ), MALDI-TOF-MS, and $\mathrm{C}, \mathrm{H}, \mathrm{N}$ analysis. The surface morphological characteristics of the final dendrimer were understood by Scanning Electronic Microscopic study (SEM). The thermal stability of the final dendrimer was studied by TGA/DTA analysis.
\end{abstract}

Key Words: Phosphorus-containing dendrimer, Divergent synthesis, Schiff's base, SEM, TGA

\section{Introduction}

Dendrimers are unique class of macromolecules that are prepared through divergent or convergent iterative procedures to different 'compounds' or materials. Dendrimers have attracted a tremendous interest since the early papers on the dendrimers by Vogtle ${ }^{1}$, Tomalia ${ }^{2}$ and Newkome. ${ }^{3}$ There are several thousand papers published on the subject and several review articles of dendrimers have been written. ${ }^{4-7}$ Many potential applications ${ }^{8}$ of dendrimers are based on their unparalleled molecular uniformity, multifunctional surface and presence of internal cavities. These specific properties make dendrimers suitable for a variety of high technology uses including biomedical and industrial applications. It has been a progressing field of research and at present all the environment friendly industrial applications based on their nanostructures are under study. ${ }^{9}$ In this perspective electron microscopic study and the thermal stability appear as an important point for most applications of phosphorus-containing dendrimers. The element phosphorus brings ease of synthesis, helps with characterization ${ }^{10}$ and gives properties seldom or never found for other dendrimers, such as high dipole moment values, ${ }^{11}$ or formation of hydrogels ${ }^{12}$ and vesicles ${ }^{13}$ in water. The presence of phosphorus as a component of the backbone of the dendrimers gives the unique behaviour. ${ }^{14}$ The Phosphorus-containing dendrimers share several properties with other types of dendrimers, for instance concerning catalysis, creation of new materials and modifications of surface materials. ${ }^{15}$ Phosohorus dendrimers have applications in materials science, ${ }^{16}$ as hydrogels, ${ }^{17}$ in DNA transfection experiments, ${ }^{18}$ as an 'anti-prion agent', ${ }^{19}$ in catalysis ${ }^{20}$ and in drug delivery. ${ }^{21}$ However, IR and Raman spectra of dendrimers up to now were used mainly for the analytical purposes. ${ }^{22}$ Now the use of matrix-assisted laser desorption ionization time-of-flight mass spectrometry (MALDI-TOF-MS) as a method of analysing the high molecular weight dendrimer since the ion current is spread over a very large number of molecules.
In this paper, we herein report the synthesis and characterization of five generations of dendritic macromolecule with 8 terminal 4-methyleneoxy but-2-yn-1-ol groups, and using 4,4'sulphonyldiphenol as the core. Nuclear magnetic resonance (NMR) experiments were carried out for the identification of the protons, and MALDI-TOF-MS was used for the mass determination of the dendrimer. With MALDI, along with ${ }^{1} \mathrm{H},{ }^{13} \mathrm{C}$ and ${ }^{31} \mathrm{P}$, we were able to precisely determine the structure of the dendrimer (5).

\section{Results and Discussion}

The synthetic strategy for novel phosphorus containing dendrimer (5) containing 4,4'-sulphonyldiphenol as core is presented in Scheme 1. The 4,4'-sulphonyldiphenol was used as core and dendrons are built around it, based on its solubility and commercial availability of the substrates. In the synthesis of compound $\mathbf{1}$, a condensation reaction of 1 molar equivalent of 4,4'-sulphonyldiphenol with two equivalents of $\mathrm{POCl}_{3}$ in presence of triethylamine (base) at 0 to $-15^{\circ} \mathrm{C}$ in dry THF with stirring for $3 \mathrm{~h}$. After filtration, in the second step, 1 was treated with 4 equivalents of 3 -aminophenol in dry THF in presence of triethylamine at $35-40{ }^{\circ} \mathrm{C}$ with stirring for $4 \mathrm{~h}$ to form compound 2 . After filtration, compound 2 was reacted with 4 equivalents of 3-hydroxy-benzaldehyde with stirring for $5 \mathrm{~h}$ in refluxing dry EtOH to afford compound $\mathbf{3}$. The compound $\mathbf{3}$ was treated with 4 equivalents of $\mathrm{P}(\mathrm{S}) \mathrm{Cl}_{3}$ in presence of triethylamine at 0 to $-15^{\circ} \mathrm{C}$ in dry THF with stirring for $5 \mathrm{~h}$ to afford the corresponding compound 4 . The compound 4 was then treated with 8 equivalents of 2-butyn -1, 4 diol in presence of triethylamine at $40-45^{\circ} \mathrm{C}$ in dry THF with stirring for $6 \mathrm{~h}$ to obtain the dendrimer 5 . As the size of the dendron increases, the reaction is sluggish and the yield is low. To improve the yield of 5 THF is taken in excess and the temperature is maintained at $40-45$ ${ }^{\circ} \mathrm{C}$ and continued stirring for longer period. Synthesis of the dendrimer 5 was accomplished by adopting divergent approach 


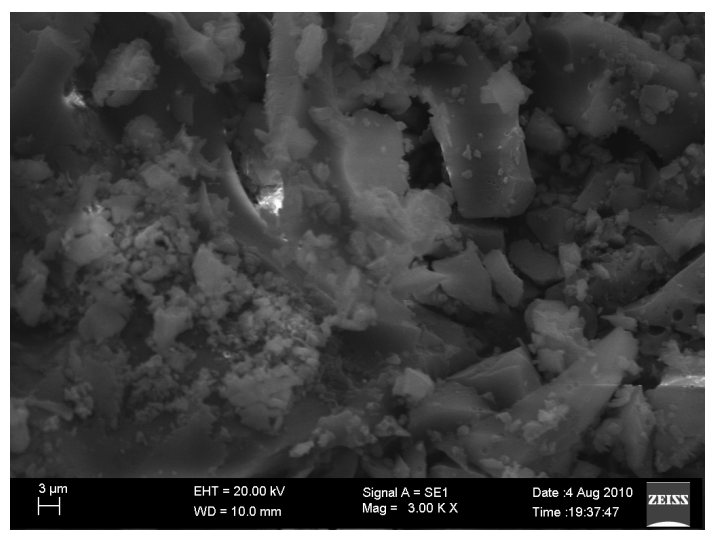

Figure 1. SEM picture of the dendrimer 5.

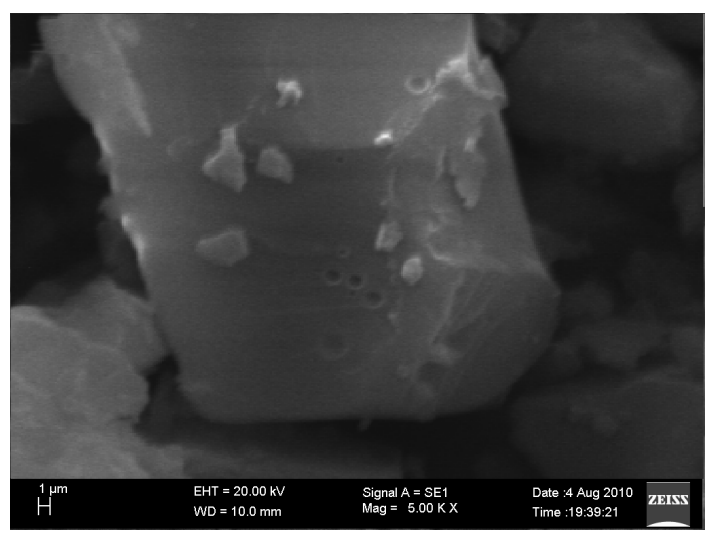

Figure 2. Particle structure of dendrimer 5.

as shown in Scheme 1. The overall yield of the final dendrimer 5 was $61 \%$. The formation of all the intermediate compounds 1, 2, 3 and 4 were characterized by IR, NMR $\left({ }^{1} \mathrm{H},{ }^{13} \mathrm{C}\right.$ and $\left.{ }^{31} \mathrm{P}\right)$, and LC-MS data. Their data are given in the experimental part. (See Supporting information file). The synthetic and analytical data of the dendrimer $\mathbf{5}$ is also presented in the experimental part. (See supporting information file). The dendrimer 5 exhibited absorption bands for $-\mathrm{OH}, \mathrm{P}=\mathrm{O}, \mathrm{P}=\mathrm{S}$ and $\mathrm{CH}=\mathrm{N}$ in the regions $3358,1226,775$ and $1602 \mathrm{~cm}^{-1}$ respectively. $\mathrm{P}-\mathrm{O}-\mathrm{C}_{(\text {aromatic) }}$ gave two absorptions in the regions 900 and $1147 \mathrm{~cm}^{-1} .^{23} \mathrm{In}$ the ${ }^{1} \mathrm{H}$ NMR spectra $(400 \mathrm{MHz})$ of $\mathbf{5}$, the aromatic protons gave multiplets in the region $\delta 6.91-7.78$, the $-\mathrm{OH}$ protons resonated at $\delta 3.86$ as singlet and the imine $\mathrm{CH}$ protons $(\mathrm{CH}=\mathrm{N})$ gave singlet at $\delta$ 9.92. The $-\mathrm{CH}_{2}-\mathrm{O}$ - protons gave singlet at $\delta 4.09$. (see supporting information). ${ }^{13} \mathrm{C}$ NMR spectrum was recorded for 5 (see supporting information) and the data are given in the experimental part. The aromatic carbons resonated in the region $105.0-115.9 \mathrm{ppm}$. $-\mathrm{CH}=\mathrm{N}$ Carbon signal was observed at $\delta$ 161.6. The compounds 4 and 5 showed two ${ }^{31} \mathrm{P}$ NMR signals indicating two different types of phosphorus atoms. The intermediate compounds 1, 2 and 3 gave phosphorus -31 resonance signals at $\delta-8.32,-11.96$ and -13.73 respectively. The mass spectral properties of the final dendrimer $\mathbf{5}$ was studied by Matrix Assisted Laser Desorption/Ionisation (MALDI-TOF) mass spectrometry. As expected, the mass obtained from the MALDI measurements corresponds closely to the calculated value (Table 8). The surface topography of the dendrimer 5 was

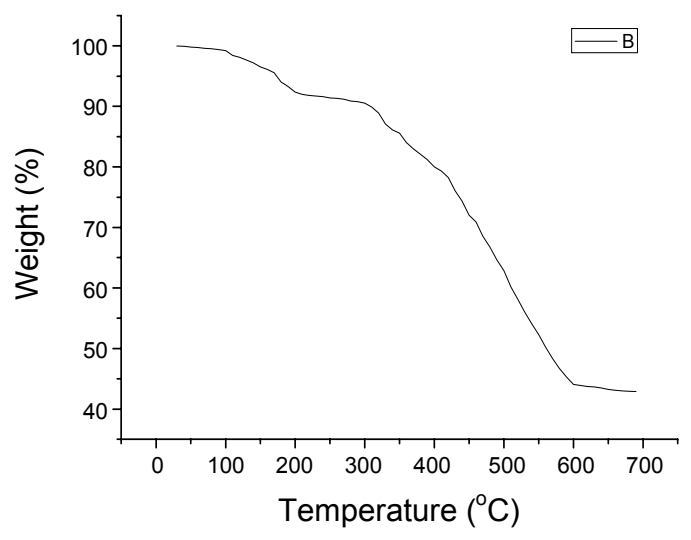

Figure 3. TGA of 5.

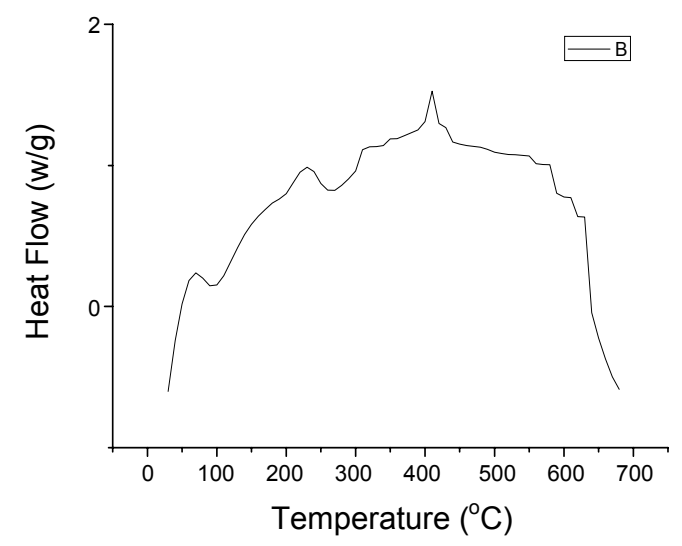

Figure 4. DTA of 5.

studied by Scanning Electron Microscopy (SEM), while the molecular decomposition of the dendrimer 5 was investigated by both thermo gravimetric analysis (TGA) and differential thermal analysis (DTA).

Scanning Electronic Microscopic Study. SEM images depict the surface structure of the dendritic material 5. In order to get a deeper insight into the surface structural characteristics of the dendritic meterial 5, we have examined it by Scanning electron microscopic analysis. With increasing the size it was clear that the overall surface morphology of the material tended to assume a nanoscale size granular shape at a line width of 3 $\mu \mathrm{M}$. Figure 1 shows the micrograph of the material with a line width of $3 \mu \mathrm{M}$ and Figure 2 shows the particle structure of the material with a line width of $1 \mu \mathrm{M}$. It was clear that the nanoscale sized morphology of the resultant dendrimer 5 was observed.

TGA-DTA Analysis. Simultaneous TGA-DTA measures both heat flow and weight changes (TGA) in a material as a function of temperature in a controlled air atmosphere was recorded. An overlay of TGA and DTA plots for the test compound (5) upto $700{ }^{\circ} \mathrm{C}$ in air atmosphere is shown in Figure 3 and Figure 4. The decomposition of the final dendritic macromolecule was followed by TGA. A typical trace can be seen in Fig. 3. An initial decomposition starts between the range $100-200{ }^{\circ} \mathrm{C}$ with a corresponding weight loss of approximately $8-10 \%$. This is attributed to the loss of water molecules. Again the decomposition starts between the range $300-680{ }^{\circ} \mathrm{C}$ with a corresponding weight loss of approximately $48-50 \%$. This account for loss of 
around sixty five per cent of the total mass of the molecule. Similarly, Differential thermal analysis (DTA), is also tested on 5 to detect the changes in the sample, either exothermic or endothermic. The DTA profile (Figure 4) shows the endotherm peaks at $100{ }^{\circ} \mathrm{C}$ corresponds to the loss of water and exotherm at $450{ }^{\circ} \mathrm{C}$, corresponds to the loss of most of the compound. Similarly some other exothermic or endothermic peaks around at different temperatures are connected with oxidation of small dendritic wedge groups of $\mathbf{5}$.

\section{Experimental}

All chemicals used in this study were purchased from SigmaAldrich Chemical Company and used without further purification. All solvents (AR or extra pure grade) were dried by standard methods. TLC was performed on precoated plates with silica gel $60 \mathrm{~F}_{254}$ (Merk).Column chromatography was performed on silica gel (0.040 - $0.063 \mathrm{~mm}$, Macherey Nagel). The Melting points were determined using a calibrated thermometer by Guna Digital Melting Point apparatus and are uncorrected. IR Spectra were recorded on JASCO Japan FT/IR-5300 Spectrometer at University of Hyderabad using $\mathrm{KBr}$ optics. ${ }^{1} \mathrm{H}$ and ${ }^{13} \mathrm{C}$ NMR spectra were recorded on a Bruker A VIII $400 \mathrm{MHz}$ NMR spectrometer at Laila Impex Vizayawada, operating at 400.13 $\mathrm{MHz}$ for ${ }^{1} \mathrm{H}, 100.61 \mathrm{MHz}$ for ${ }^{13} \mathrm{C} \mathrm{NMR}$, data were recorded in DMSO- $d_{6}$ and chemical shifts were referenced to TMS $\left({ }^{1} \mathrm{H}\right.$ and $\left.{ }^{13} \mathrm{C}\right) .{ }^{31} \mathrm{P}$ NMR spectra were recorded on Bruker ACF Supercon 200 spectrometer operating at $81 \mathrm{MHz}$ at University of Hyderabad, Hyderabad. ${ }^{31} \mathrm{P}$ NMR data were recorded in $\mathrm{CDCl}_{3}$ and chemical shifts were referenced to $85 \% \mathrm{H}_{3} \mathrm{PO}_{4}$. LC Mass spectra of intermediate compounds were recorded on LCMS-2010A Shimadzu, spectrometer at University of Hyderabad, Hyderabad. MALDI mass spectrum of the final dendrimer 5 was recorded using Applied Biosystems MALDI-TOF Voyger depro spectrometer. The sample was run using Sinapic acid as the matrix with DMSO as the solvent in dried-droplet preparation method, performed at IIT, Madras, Chennai. TGA-DTA measurement was taken using TA instrument, waterloo, USA, performed at Sri Krishnadevaraya University, Ananthapur, India. Scanning Electron Microscopy (SEM) images were taken with a Carl Zeiss, EVO MA15 Instrument. SEM operated at $20 \mathrm{kV}$, performed at Department of Physics, S. V. University, Tirupati, India. Elemental analyses were performed using FLASH EA 1112 Thermo Finnigan instrument, France, at University of Hyderabad, Hyderabad, India.

General Procedure for Synthesis of Dendrimer 5.

Preparation of 1: A solution $(0.01 \mathrm{~mol}, 0.93 \mathrm{~mL})$ of $\mathrm{POCl}_{3}$ in $20 \mathrm{~mL}$ of dry THF was added dropwise over a period of 20 min to a mixture of stirred solution of 4,4'-sulphonyldiphenol $(0.005 \mathrm{~mol}, 0.43 \mathrm{~g})$ in $25 \mathrm{~mL}$ of dry THF and triethylamine $(0.01$ $\mathrm{mol}, 1.4 \mathrm{~mL})$ at $0-15^{\circ} \mathrm{C}$. After stirring for $3 \mathrm{~h}$ at $35-40^{\circ} \mathrm{C}$, formation of 1 was ascertained by TLC analysis run in a 2:8 mixture of ethyl acetate and hexane and the average $R_{f}$ value observed was 0.71 . Triethylamine hydrochloride was removed by filtration. The filtrate was used for the next reaction step without further purification. The compound thus obtained was characterized by IR, NMR $\left({ }^{1} \mathrm{H},{ }^{13} \mathrm{C}\right.$ and $\left.{ }^{31} \mathrm{P}\right), \mathrm{LC}$-mass and $\mathrm{C}, \mathrm{H}, \mathrm{N}$ analysis and used for the next reaction step.
Table 1. Analytical data of 1

\begin{tabular}{ccccccc}
\hline \multirow{2}{*}{ Compound } & \multirow{2}{*}{$\begin{array}{c}\text { Yield } \\
\%\end{array}$} & $\begin{array}{c}\text { Molecular } \\
\text { formula }\end{array}$ & & \multicolumn{3}{c}{$\begin{array}{c}\text { Elemental analysis } \\
\text { (found/calculated) }\end{array}$} \\
\cline { 4 - 7 } & & & $\mathrm{C}$ & $\mathrm{H}$ & $\mathrm{N}$ \\
\hline $\mathbf{1}$ & 81 & $\mathrm{C}_{12} \mathrm{H}_{8} \mathrm{Cl}_{4} \mathrm{O}_{6} \mathrm{P}_{2} \mathrm{~S}$ & $29.68 / 29.78$ & $1.61 / 1.67$ & - \\
\hline
\end{tabular}

Table 2. IR, and LC-Mass of 1

\begin{tabular}{|c|c|c|c|}
\hline \multirow{2}{*}{ Compound } & \multicolumn{2}{|c|}{$\mathrm{IR}\left(\mathrm{KBr}, \mathrm{cm}^{-1}\right)$} & \multirow{2}{*}{ LC- Mass: $m / z$} \\
\hline & $\mathrm{P}=\mathrm{O}$ & P-O-C $\mathrm{C}_{\text {aromatic }}$ & \\
\hline 1 & 1235 & $\begin{array}{c}935 \\
1170\end{array}$ & $\begin{array}{c}484.00 \\
{[\mathrm{M}]^{+} .}\end{array}$ \\
\hline
\end{tabular}

Table 3. ${ }^{1} \mathrm{H},{ }^{13} \mathrm{C}$ and ${ }^{31} \mathrm{P}$ NMR Spectral data of $\mathbf{1}$

${ }^{1} \mathrm{H}$ NMR (400 MHz, DMSO- $\left.d_{6}\right), \delta$ 6.91-6.94 $(4 \mathrm{H}, \mathrm{d}$, Ar-H, $J=8.4 \mathrm{~Hz}), 7.70-7.72(4 \mathrm{H}, \mathrm{d}, \mathrm{Ar}-\mathrm{H}, J=8.4 \mathrm{~Hz})$.

Compound $1{ }^{13} \mathrm{C}$ NMR (100 MHz, DMSO- $\left.d_{6}\right), \delta 132.0\left(\mathrm{C}_{0}{ }^{1}\right), 129.2$ $\left(\mathrm{C}_{0}^{2} / \mathrm{C}_{0}^{6}\right), 115.9\left(\mathrm{C}_{0}^{3} / \mathrm{C}_{0}^{5}\right), 161.6\left(\mathrm{C}_{0}^{4}\right)$.

${ }^{31} \mathrm{P}$ NMR $\left(81 \mathrm{MHz}, \mathrm{CDCl}_{3}\right), \delta-8.32$

Table 4. Analytical data of 2

\begin{tabular}{llllll}
\hline \multirow{2}{*}{ Compound $\begin{array}{c}\text { Yield } \\
\%\end{array}$} & $\begin{array}{c}\text { Molecular } \\
\text { formula }\end{array}$ & & \multicolumn{3}{c}{$\begin{array}{c}\text { Elemental analysis } \\
\text { (found/calculated) }\end{array}$} \\
\cline { 3 - 6 } & & & $\mathrm{C}$ & $\mathrm{H}$ & $\mathrm{N}$ \\
\hline
\end{tabular}

2

$75 \quad \mathrm{C}_{36} \mathrm{H}_{32} \mathrm{~N}_{4} \mathrm{O}_{10} \mathrm{P}_{2} \mathrm{~S} \quad 55.76 / 55.82$ 4.22/4.16 7.28/7.23

Table 5. IR, and LC-Mass of 2

\begin{tabular}{ccccc}
\hline \multirow{2}{*}{ Compound } & \multicolumn{3}{c}{$\mathrm{IR}\left(\mathrm{KBr}, \mathrm{cm}^{-1}\right)$} & LC- Mass: $m / z$ \\
\cline { 2 - 5 } & $\mathrm{P}=\mathrm{O}$ & $\mathrm{P}-\mathrm{O}-\mathrm{C}_{\text {aromatic }}$ & $-\mathrm{NH}_{2}$ & \\
\hline \multirow{2}{*}{2} & 1232 & 920,1155 & $\begin{array}{c}3190(\text { str) } \\
1493 \text { (bending) }\end{array}$ & $\begin{array}{c}776.0 \\
{[\mathrm{M}+1]^{+}}\end{array}$ \\
\hline
\end{tabular}

Table 6. ${ }^{1} \mathrm{H},{ }^{13} \mathrm{C}$ and ${ }^{31} \mathrm{P}$ NMR Spectral data ${ }^{\mathrm{a}, \mathrm{b}}$ of 2

\begin{aligned} & \hline${ }^{1} \mathrm{H} N M R\left(400 \mathrm{MHz}, \mathrm{DMSO}-d_{6}\right), \delta 6.02-7.70(24 \mathrm{H}, \mathrm{m} \\ &,\mathrm{Ar}-\mathrm{H}), 5.95\left(8 \mathrm{H}, \mathrm{s}, \mathrm{Ar}_{-} \mathrm{NH}_{2}\right) \\ &.{ }^{13} \mathrm{C} \mathrm{NMR}\left(100 \mathrm{MHz}, \mathrm{DMSO}_{6}\right), \delta 132.5\left(\mathrm{C}_{0}{ }^{1}\right), 129.8 \\ &$ Compound 2 $\left(\mathrm{C}_{0}{ }^{2} / \mathrm{C}_{0}{ }^{6}\right), 116.4\left(\mathrm{C}_{0}{ }^{3} / \mathrm{C}_{0}{ }^{5}\right), 158.5\left(\mathrm{C}_{0}{ }^{4}\right), 149.6\left(\mathrm{C}_{1}{ }^{1}\right) \\ &, 101.8\left(\mathrm{C}_{1}^{2}\right), 162.0\left(\mathrm{C}_{1}{ }^{3}\right), 104.2\left(\mathrm{C}_{1}{ }^{4}\right), 129.9\left(\mathrm{C}_{1}{ }^{5}\right), 106.2 \\ &\left(\mathrm{C}_{1}^{6}\right) \\ &.{ }^{31} \mathrm{P} \mathrm{NMR}\left(81 \mathrm{MHz}, \mathrm{CDCl}_{3}\right), \delta-11.96 \\ &$\hline\end{aligned}

Preparation of 2: To a mixture of stirred solution of the filtrate 1 and triethylamine $(0.02 \mathrm{~mol}, 2.8 \mathrm{~mL})$, a solution of 3-aminophenol $0.02 \mathrm{~mol}, 4.35 \mathrm{~g}$ ) in $25 \mathrm{~mL}$ of dry THF was added dropwise over a period of $20 \mathrm{~min}$ at $0-15^{\circ} \mathrm{C}$. After stirring for $4 \mathrm{~h}$ at $35-40^{\circ} \mathrm{C}$, formation of $\mathbf{2}$ was ascertained by TLC analysis run in a 3:7 mixture of ethyl acetate and hexane and the average $R_{f}$ value observed was 0.67 . Triethylamine hydrochloride was removed by filtration. The solvent was evaporated under reduced pressure to give crude product. It was purified by column chro- 
Table 7. Analytical data of 3

\begin{tabular}{llllll}
\hline \multirow{2}{*}{ Compound } & Yield & Molecular & & \multicolumn{3}{c}{$\begin{array}{c}\text { Elemental analysis } \\
\text { (found/calculated) }\end{array}$} \\
\cline { 3 - 6 } & formula & C & H & $\mathrm{N}$ \\
\hline
\end{tabular}

$3 \quad 65 \quad \mathrm{C}_{64} \mathrm{H}_{48} \mathrm{~N}_{4} \mathrm{O}_{14} \mathrm{P}_{2} \mathrm{~S} \quad 64.45 / 64.54$ 4.12/4.06 4.78/4.70

Table 8. IR, and LC-Mass of 3

\begin{tabular}{cccccc}
\hline \multirow{2}{*}{ Compound } & \multicolumn{4}{c}{$v_{\max }\left(\mathrm{KBr}, \mathrm{cm}^{-1}\right),(\mathrm{IR})$} & LC-Mass: $m / z$ \\
\cline { 2 - 5 } & $\mathrm{P}=\mathrm{O}$ & $\mathrm{P}-\mathrm{O}-\mathrm{C}_{\text {aromatic }}$ & $\mathrm{HC}=\mathrm{N}$ & Ar-OH & \\
\hline 3 & 1226 & 960,1153 & 1602 & 3339 & $1189.4[\mathrm{M}-1]^{+}$ \\
\hline
\end{tabular}

Table 9. ${ }^{1} \mathrm{H},{ }^{13} \mathrm{C}$ and ${ }^{31} \mathrm{P}$ NMR Spectral data of $\mathbf{3}$

${ }^{1} \mathrm{H}$ NMR (400 MHz, DMSO- $\left.d_{6}\right), \delta 9.74$ (4H, s, Aromatic-OH), $8.95(4 \mathrm{H}, \mathrm{s},-\mathrm{CH}=\mathrm{N}), 6.90-7.37(40 \mathrm{H}, \mathrm{m}$, Ar-H).

${ }^{13} \mathrm{C}$ NMR $\left(100 \mathrm{MHz}, \mathrm{DMSO}-d_{6}\right), \delta 132.6\left(\mathrm{C}_{0}{ }^{1}\right), 128.8$

Compound $3\left(\mathrm{C}_{0}{ }^{2} / \mathrm{C}_{0}{ }^{6}\right), 117.0\left(\mathrm{C}_{0}{ }^{3} / \mathrm{C}_{0}{ }^{5}\right), 158.1\left(\mathrm{C}_{0}{ }^{4}\right), 150.0\left(\mathrm{C}_{1}{ }^{1}\right)$, $107.5\left(\mathrm{C}_{1}^{2}\right), 162.1\left(\mathrm{C}_{1}^{3}\right), 103.0\left(\mathrm{C}_{1}^{4}\right), 129.5\left(\mathrm{C}_{1}^{5}\right), 110.1$ $\left(\mathrm{C}_{1}^{6}\right), 140.0\left(\mathrm{C}_{2}^{1}\right), 114.0\left(\mathrm{C}_{2}{ }^{2}\right), 156.5\left(\mathrm{C}_{2}^{3}\right), 120.5\left(\mathrm{C}_{2}{ }^{4}\right)$, $130.8\left(\mathrm{C}_{2}^{5}\right), 122.4\left(\mathrm{C}_{2}{ }^{6}\right), 166.5(\mathrm{CH}=\mathrm{N})$. ${ }^{31} \mathrm{P}$ NMR $\left(81 \mathrm{MHz}, \mathrm{CDCl}_{3}\right), \delta-11.73$

matography on silica gel (60 - 120 mesh, ethyl acetate:hexane, $2: 8)$ to afford the pure compound. The compound thus obtained was characterized by IR, NMR $\left({ }^{1} \mathrm{H},{ }^{13} \mathrm{C}\right.$ and $\left.{ }^{31} \mathrm{P}\right), \mathrm{LC}$-mass and $\mathrm{C}, \mathrm{H}, \mathrm{N}$ analysis and used for the next reaction step.

Preparation of 3: To a stirred solution of 2 in $25 \mathrm{~mL}$ of dry EtOH, a solution of 3-hydroxy-benzaldehyde ( $0.02 \mathrm{~mol}, 4.88 \mathrm{~g})$ in $25 \mathrm{~mL}$ of dry EtOH, was added at room temperature. After stirring for $5 \mathrm{~h}$ at reflux temperature, formation of $\mathbf{3}$ was ascertained by TLC analysis run in a 4:6 mixture of ethyl acetate and hexane and the average $R_{f}$ value observed was 0.62 . The solvent was evaporated under reduced pressure to give crude product. It was purified by washing with ethyl acetate and hexane. The imine thus obtained was characterized by IR, NMR $\left({ }^{1} \mathrm{H},{ }^{13} \mathrm{C}\right.$ and $\left.{ }^{31} \mathrm{P}\right), \mathrm{LC}$-mass and $\mathrm{C}, \mathrm{H}, \mathrm{N}$ analysis and used for the next reaction step.

Preparation of 4: To a stirred solution of 3 in $30 \mathrm{~mL}$ of dry THF, a solution of $\mathrm{P}(\mathrm{S}) \mathrm{Cl}_{3}(0.02 \mathrm{~mol}, 4.06 \mathrm{~mL})$ in $25 \mathrm{~mL}$ of dry $\mathrm{THF}$, was added dropwise over a period of $20 \mathrm{~min}$ at $0-15^{\circ} \mathrm{C}$. After stirring for $5 \mathrm{~h}$ at $35-40^{\circ} \mathrm{C}$, formation of 4 was ascertained by TLC analysis run in a 1:1 mixture of ethyl acetate and hexane and the average $R_{f}$ value observed was 0.60 . The solvent was evaporated under reduced pressure to get crude product. It was purified by column chromatography on silica gel (60 - 120 mesh, ethyl acetate:hexane, 1:1) to afford the pure compound. The compound thus obtained was characterized by IR, NMR $\left({ }^{1} \mathrm{H},{ }^{13} \mathrm{C}\right.$ and $\left.{ }^{31} \mathrm{P}\right), \mathrm{LC}$-mass and $\mathrm{C}, \mathrm{H}, \mathrm{N}$ analysis and used for the next reaction step.

Preparation of 5: To a stirred solution of 4 in $30 \mathrm{~mL}$ of dry THF, a solution of 2-butyne 1, 4-diol ( $0.04 \mathrm{~mol}, 6.88 \mathrm{~g})$ in $25 \mathrm{~mL}$ of dry THF, was added dropwise over a period of $20 \mathrm{~min}$ at $0-15^{\circ} \mathrm{C}$. After stirring for $5 \mathrm{~h}$ at $40-45^{\circ} \mathrm{C}$, formation of 5 was ascertained by TLC analysis run in a 7:3 mixture of ethyl acetate
Table 10. Analytical data of 4

\begin{tabular}{lllll}
\hline \multirow{2}{*}{ Compound } & Yield & Molecular & & \multicolumn{3}{c}{$\begin{array}{c}\text { Elemental analysis } \\
\text { (found/calculated) }\end{array}$} \\
\cline { 3 - 5 } & formula & $\mathrm{C}$ & $\mathrm{H}$ & $\mathrm{N}$ \\
\hline
\end{tabular}

4

$63 \mathrm{C}_{64} \mathrm{H}_{48} \mathrm{~N}_{4} \mathrm{O}_{14} \mathrm{P}_{6} \mathrm{~S}_{5} \quad 44.56 / 44.62 \quad$ 2.53/2.57 3.32/3.25

Table 11. IR, and LC- Mass of 4

\begin{tabular}{cccccc}
\hline \multirow{2}{*}{ Compound } & \multicolumn{5}{c}{$v_{\max }\left(\mathrm{KBr}, \mathrm{cm}^{-1}\right),(\mathrm{IR})$} \\
\cline { 2 - 5 } & $\mathrm{P}=\mathrm{O}$ & $\mathrm{P}=\mathrm{S}$ & $\mathrm{P}-\mathrm{O}-\mathrm{C}_{\text {aromatic }}$ & $\mathrm{CH}=\mathrm{N}$ & LC-Mass: $\mathrm{m} / z$ \\
\hline 4 & 1230 & 788 & 974,1159 & 1615 & $1723[\mathrm{M}+1]^{+.}$ \\
\hline
\end{tabular}

Table 12. ${ }^{1} \mathrm{H},{ }^{13} \mathrm{C}$ and ${ }^{31} \mathrm{P}$ NMR Spectral data, ${ }^{\mathrm{a}, \mathrm{b}}$ of 4

${ }^{1} \mathrm{HNMR}\left(400 \mathrm{MHz}, \mathrm{DMSO}-d_{6}\right), \delta 8.41(4 \mathrm{H}, \mathrm{s},-\mathrm{CH}=\mathrm{N})$, 7.22-7.81(40 H, m, Ar-H).

${ }^{13} \mathrm{C}$ NMR (100 MHz, DMSO- $\left.d_{6}\right), \delta 132.0\left(\mathrm{C}_{0} 1\right), 129.5$

$\left(\mathrm{C}_{0}^{2} / \mathrm{C}_{0}^{6}\right), 116.0\left(\mathrm{C}_{0}^{3} / \mathrm{C}_{0}^{5}\right), 162.8\left(\mathrm{C}_{0}^{4}\right), 151.9\left(\mathrm{C}_{1}^{1}\right)$,

Compound 4 108.0 $\left(\mathrm{C}_{1}^{2}\right), 161.9\left(\mathrm{C}_{1}^{3}\right), 110.0\left(\mathrm{C}_{1}^{4}\right), 129.2\left(\mathrm{C}_{1}^{5}\right), 115.9$ $\left(\mathrm{C}_{1}^{6}\right), 138.1\left(\mathrm{C}_{2}^{1}\right), 118.2\left(\mathrm{C}_{2}^{2}\right), 158.0\left(\mathrm{C}_{2}^{3}\right), 120.5\left(\mathrm{C}_{2}^{4}\right)$, $131.2\left(\mathrm{C}_{2}^{5}\right), 123.5\left(\mathrm{C}_{2}{ }^{6}\right), 166.5(\mathrm{CH}=\mathrm{N})$.

${ }^{31} \mathrm{P}$ NMR $\left(81 \mathrm{MHz}, \mathrm{CDCl}_{3}\right), \delta 74.01,-22.40$

Table 13. Analytical data of 5

\begin{tabular}{ccccc}
\hline \multirow{2}{*}{ Compound } & \multirow{2}{*}{$\begin{array}{c}\text { Yield } \\
\%\end{array}$} & $\begin{array}{c}\text { Molecular } \\
\text { formula }\end{array}$ & & \multicolumn{3}{c}{$\begin{array}{c}\text { Elemental analysis } \\
\text { (found/calculated) }\end{array}$} \\
\cline { 3 - 6 } & & $\mathrm{C}$ & $\mathrm{H}$ & $\mathrm{N}$ \\
\hline
\end{tabular}

5

$61 \quad \mathrm{C}_{96} \mathrm{H}_{84} \mathrm{~N}_{4} \mathrm{O}_{30} \mathrm{P}_{6} \mathrm{~S}_{5} \quad 54.48 / 54.39$ 3.89/3.99 2.59/2.64

Table 14. Infrared spectral data $\left(\mathrm{cm}^{-1}\right)$ of 5

\begin{tabular}{cccccc}
\hline \multirow{2}{*}{ Compound } & \multicolumn{5}{c}{$\mathrm{v}_{\max }\left(\mathrm{KBr}, \mathrm{cm}^{-1}\right),(\mathrm{IR})$} \\
\cline { 2 - 6 } & $-\mathrm{OH}$ & $\mathrm{P}=\mathrm{O}$ & $\mathrm{P}=\mathrm{S}$ & $\mathrm{P}-\mathrm{O}-\mathrm{C}_{\text {aromatic }}$ & $\mathrm{CH}=\mathrm{N}$ \\
\hline $\mathbf{5}$ & 3358 & 1226 & 775 & 900,1147 & 1602 \\
\hline
\end{tabular}

Table 15. ${ }^{1} \mathrm{H},{ }^{13} \mathrm{C}$ and ${ }^{31} \mathrm{P}$ NMR Spectral data ${ }^{\mathrm{a}, \mathrm{b}}$ of 5

${ }^{1} \mathrm{H}$ NMR (400 MHz, DMSO- $\left.d_{6}\right), \delta 3.86(8 \mathrm{H}, \mathrm{s}$, Aliphatic-OH), 6.91-7.78 (40H, m, Ar-H), $9.92(4 \mathrm{H}, \mathrm{s}$, $-\mathrm{CH}=\mathrm{N}), 4.09\left(32 \mathrm{H}, \mathrm{s},-\mathrm{CH}_{2}-\mathrm{O}-\right)$.

${ }^{13} \mathrm{C}$ NMR (100 MHz, DMSO- $\left.d_{6}\right), \delta 45.5$

$\left(\mathrm{O}-\stackrel{\mathrm{H}_{2}}{-}-\mathrm{C} \equiv \mathrm{C}-\stackrel{\mathrm{C}}{2}_{2}-\mathrm{OH}\right), 49.0$

${ }^{\mathrm{H}_{2}}-\mathrm{C} \equiv \mathrm{C}-\mathrm{H}_{2}$

Compound 5

政 -83.9

$\left(\mathrm{O}-\mathrm{C}-\mathrm{C} \equiv \underline{\mathrm{C}}-\mathrm{C}^{2}-\mathrm{OH}\right), 90.0$

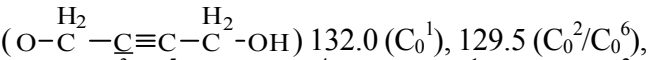
$116.0\left(\mathrm{C}_{0}{ }^{3} / \mathrm{C}_{0}^{5}\right), 155.9\left(\mathrm{C}_{0}^{4}\right), 146.7\left(\mathrm{C}_{1}{ }^{1}\right), 105.2\left(\mathrm{C}_{1}^{2}\right)$, $151.0\left(\mathrm{C}_{1}^{3}\right), 115.9\left(\mathrm{C}_{1}^{4}\right), 129.2\left(\mathrm{C}_{1}^{5}\right), 120.5\left(\mathrm{C}_{1}^{6}\right)$, $137.2\left(\mathrm{C}_{2}{ }^{1}\right), 115.9\left(\mathrm{C}_{2}{ }^{2}\right), 142.0\left(\mathrm{C}_{2}{ }^{3}\right), 122.6\left(\mathrm{C}_{2}{ }^{4} / \mathrm{C}_{2}{ }^{6}\right)$, $128.9\left(\mathrm{C}_{2}^{5}\right), 161.6(\mathrm{CH}=\mathrm{N})$.

${ }^{31} \mathrm{P}$ NMR (81 MHz, $\left.\mathrm{CDCl}_{3}\right), \delta 55.02,-23.35$. 
Table 16. Mass data of 5 obtained from MALDI

\begin{tabular}{ccc}
\hline Dendrimer & Calculated mass & MALDI mass $(\mathrm{M})^{+}$ \\
\hline $\mathbf{5}$ & 2118.22 & 2118.00
\end{tabular}<smiles>O=P(Cl)(Cl)Oc1ccc(S(=O)(=O)c2ccc(OS(=O)(=O)Cl)cc2)cc1</smiles>

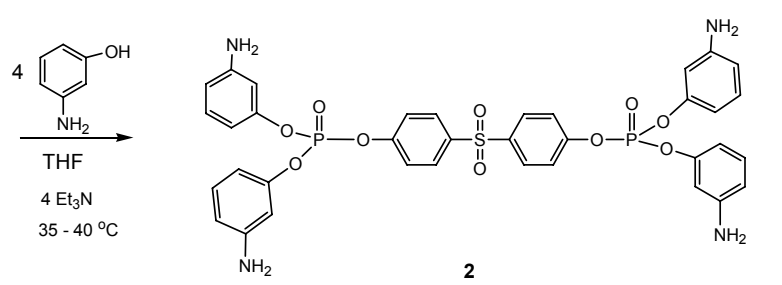

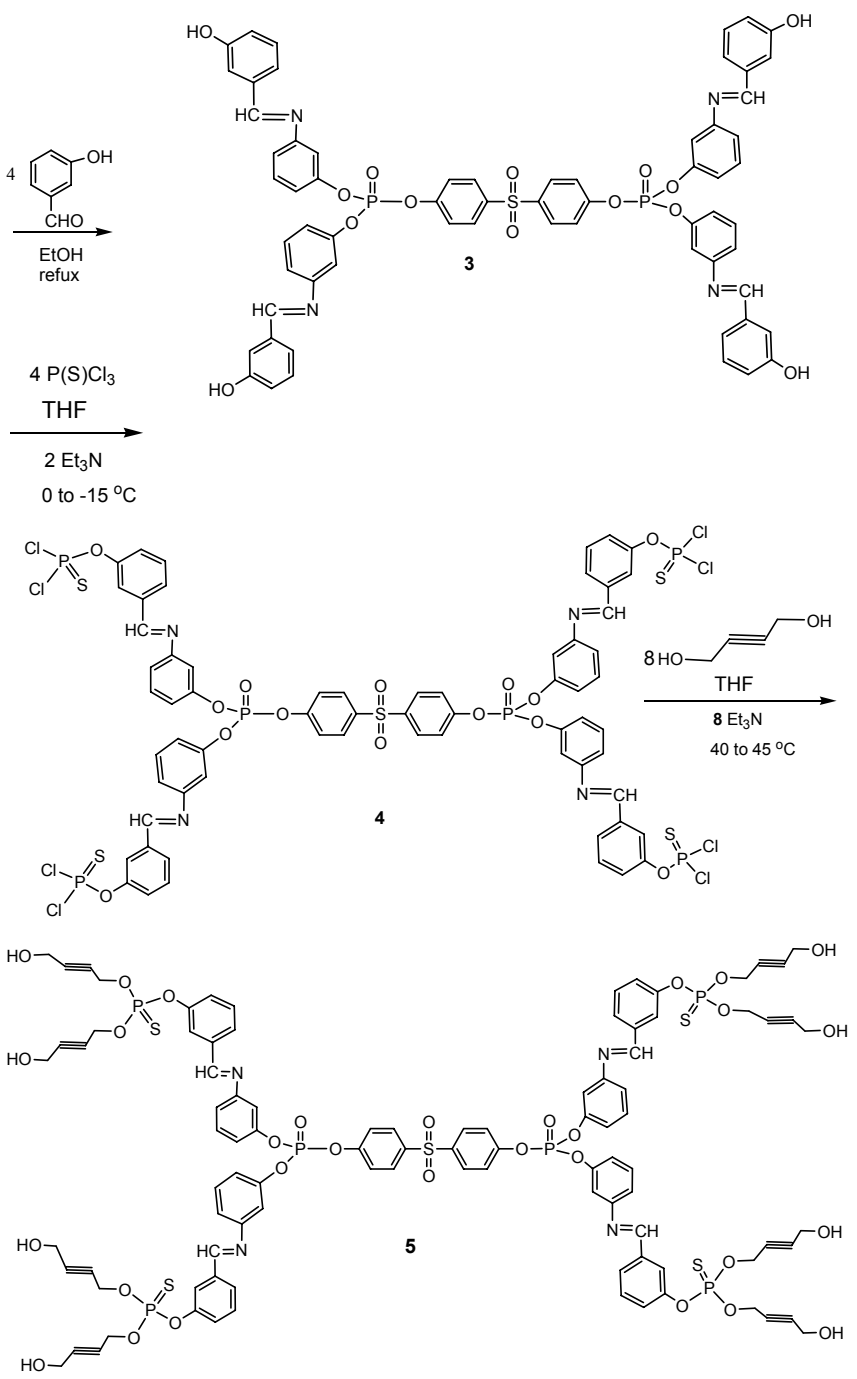

Scheme 1. Synthesis of dendrimer 5

and hexane and the average $R_{f}$ value observed was 0.45 . The solvent was evaporated under reduced pressure to get crude product. It was purified by column chromatography on silica gel (60 - 120 mesh, ethylacetate:hexane, 6:4) to afford the pure compound. The compound thus obtained was characterized by ${ }^{1} \mathrm{H},{ }^{13} \mathrm{C}$ and ${ }^{31} \mathrm{P}$ NMR, MALDI-TOF-MS, and $\mathrm{CHN}$ analysis.

\section{Conclusions}

Synthesis of a novel phosphorus dendrimer 5 was accomplished by divergent approach. The condensation reactions were performed in dry tetrahydrofuran in presence of triethylamine and the Schiff's base preparations were perfomed in dry ethanol. The deeper surface topography of the dendrimer 5 was observed by SEM image. It reveals a nano-sized molecule with a diameter of $1 \mu \mathrm{M}$. The thermal stability and changes in weight in relation to change in temperature and the heat of the final dendrimer 5 were established by TGA-DTA analysis.

Acknowledgments. The authors thank HRDG, CSIR, New Delhi, India for sanctioning a major Research project (01(2309)/ 09/EMR-II).

\section{References}

1. Buhleier, E.; Wehner, W.; Vogtle, F. Synthesis 1978, 155.

2. Tomalia, D. A.; Dewald, J. R.; 8402705. ; USA; Dow Chemical Co. 1984.

3. Newkome, G. R.; Yao, Z.; Baker, G. R.; Gupta, V. K. J. Org. Chem. 1985, 50, 2003.

4. Grayson, S. M.; Fréchet, J. M. J. Chem. Rev. 2001, 101, 3819.

5. Vogtle, F.; Gestermann, S.; Hesse, R.; Schwierz, H.; Windisch, B. Prog. Polym. Sci. 2000, 25, 987.

6. Newkome, G. R., Ed.; Advances in Dendritic Macromolecules; 1999; Vol. 4, Jai Press Inc.: USA.

7. Mathews, O. A.; Shipway, A. N.; Stoddart, J.F. Prog. Polym. Sci. 1998, 23,1 .

8. (a) Special Issue: Tomalia, D. A., Fréchet, J. M. J., Eds.; Dendrimers and Dendritic Polymers; Prog. Polym. Sci. 2005, 30, 217. (b) Majoral, J. P.; Caminade, A. M.; Maraval, V. Chem. Commun. 2002, 2929

9. Barbara, K.; Maria, B. Acta Biochimica Polonica: Dendrimers: Properties and Applications 2001, 48(1), 199.

10. Launay, N.; Caminade, A. M.; Lahana, R.; Majoral, J. P. Angew. Chem., Int. Ed. Engl. 1994, 33, 1589.

11. Lartigue, M. L.; Donnadieu, B.; Galliot, C.; Caminade, A. M.; Majoral, J. P.; Fayet, J. P. Macromolecules 1997, 30, 7335.

12. Marmillon, C.; Gauffre, F.; Gulik-Krzywicki, T.; Loup, C.; Caminade, A. M.; Majoral, J. P.; Vors, J. P.; Rump, E. Angew. Chem. Int. Ed. 2001, 40, 2626.

13. Blanzat, M.; Turrin, C. O.; Perez, E.; Rico-Lattes, I.; Caminade, A. M.; Majoral, J. P. Chem. Commun. 2002, 1864.

14. Caminade, A. M.; Maraval, V.; Laurent, R .; Majoral, J. P. Curr. Org. Chem. 2002, 6, 739.

15. Caminade, A. M.; Majoral, J. P. Prog. Polym. Sci. 2005, $30,491$.

16. Schmid, G.; Meyer-Zaika, W.; Pugin, R.; Sawitowski, T.; Majoral, J. -P.; Caminade, A.-M.; Turrin, C.-O. Chem. Eur. J. 2000, 6, 1693.

17. Marmillon, C.; Gauffre, F.; Gulik-Krzywicki, T.; Loup, C.; Caminade, A.-M.; Majoral , J.-P. ; Vors, J.-P.; Rump, E. Angew. Chem. Int. Ed. Engl. 2001, 40, 2626.

18. Boussif, O.; Zanta, M. A. Gene Ther. 1996, 3, 1074.

19. Supattapone, S.; Nguyen H. O. B.; Cohen, F. E.; Prusiner, S. B.; Scott, M. R. Proc Natl Acad Sci. 1999, 96, 14529.

20. Maraval, V.; Laurent, R.; Caminade, A. M.; Majoral, J. P. Organometallics 2000, 19, 4025.

21. Goller, R.; Vors, J.P.; Caminade, A. M.; Majoral, J. P. Tetrahedron Lett 2001, 42, 3587.

22. Davis, A. P.; Ma, G.; Allen, H. C. Anal. Chim. Acta 2003, 496, 117.

23. Thomas, L. C. Interpretation of Infrared Spectra of Organophosphorus Compounds; Heydon and Sons: London, 1974. 